\title{
Gandhian philosophy of health and hygeine in an era of pandemic
}

\author{
Baijayanti Ghosh ${ }^{1}$ \\ ${ }^{1}$ Assistant Professor, Dept. of Political Science, Krishnagar Women's College, Aurobindo \\ Sarani ,Krishnagar, District Nadia, Pin-741101, West Bengal, India \\ Email:baijayanti101@gmail.com
}

\begin{abstract}
Challenges faced by the world today aren't limited to a single sphere. Multiple avenues pose threats like never before; global warming with melting of arctic ice, raging fires in Amazon and Australia, humanitarian crisis of refugees, civil war in Libya and other parts of the world pose threats to the very Human existence. The very ecology is threatened on multiple frontiers due to these challenges. None the less, associated with this Health crisis of humongous proportions is causing catastrophe in various ways. As the world advances and countries strive to keep pace with development, the cut throat competition has worsened the health crisis more than ever. Imbalances brought by humans are no longer sustained by Mother Nature. As the environment changes rapidly Nature is unleashing its fury on us, and what could be truer in today's world gripped by a Pandemic that's unleashing its wrath. Looking back, we will see Gandhiji's simplicity in laying down models for health and hygiene are more realistic and true than ever. As we move forward in post pandemic era, Gandhiji's simple measures almost a century old, holds more value than ever before
\end{abstract}

Keywords: challenges, crisis of refugees, global warming, ecology, health crisis, humongous, proportion, catastrophe, pandemic, hygiene.

\section{INTRODUCTION}

Some great men of all times were not only geniuses, they were scholars, philosophers and social reformers and what not, to say the least, they thought well ahead of their times. Their foresight exemplary dedication to their work and simplicity in conveying their thoughts made mass movements which changed the course of history.

Mohandas Karamchand Gandhi a person above words and accolades appreciation or praises was a genius, philosopher, thinker, social reformer to say the least mere words are not sufficient to describe a personality of such magnitude. He was a freedom fighter who broke all boundaries, to put the curtain on the British Empire in India. His freedom struggle against the British is well known the world over and rightly earned him the title "Father of the Nation". Never the less the other reforms bought in by Gandhiji are equally impressive. His work on social equality of everyone including Harijans, Mehtars (Sweepers) and his work on cleanliness and sanitation are very impressive and more so in today's era. Gandhiji ones said that He wanted to achieve cleanliness first and freedom later, echoed by our Honorable Prime Minister Mr. Narendra Modi by kick starting the "Swachh Bharat" campaign. Sanitation personal hygiene, cleanliness in institutions and public buildings are encouraged. And in these times of the pandemic when we are cautious than ever, it was long back Gandhiji said no one should spit or clean their nose publicly, and today His words echo more than ever. Proper collection treatment disposal of human waste is mandatory Gandhiji said and it's just not for the betterment of the person or community in fact for the whole human race, and applies universally irrespective of caste creed religion. 


\section{LITERARY RESEARCH}

It is hard to comprehend all the actions of great Men, just to associate Gandhiji with cleanliness or his work in this field without associating his vision of a casteless society, abolishing untouchability, manual scavenging rather seems incomplete, and doesn't fulfill the goal. The broader meaning of cleanliness Gandhiji talked about was not only proper sanitation, hygiene but also clean drinking water, cleanliness of roads offices and public institutions. He stressed the importance of collection treatment and proper disposal of human waste. His idea of "Swaraj" was clear and simple, that everyone must be independent in taking care of themselves, by staying clean and keeping personal sanitation hygiene not only a priority but also keeping toilets clean. He stressed the need rightfully as He showed that cleanliness and good health are correlated. In this context He ones said "Everyone must be his own scavenger" . His ideas were very basic but hardly followed or practiced unanimously in our society, taking regular baths, washing hands before meals and brushing of teeth are equally important, and not spitting openly in public or cleaning nose. The very essence of cleanliness was embedded in Gandhiji's mind and in the simplest possible manner He conveyed the same not only to his followers but society as a whole. He pointed to the relationship between cleanliness and good health in very simple terms, and how basic habits can boost ones health and keep the whole community healthy. The very thoughts preached by Gandhiji in 1930's holds true even today. And more so ever in today's era where a global pandemic has taken the world over His words hold true more than ever.

The very idea of cleanliness wasn't limited only to personal hygiene or following basic hygiene protocols or limited to oneself. Keeping oneself healthy by staying clean, keeping roads, towns, villages and buildings clean and of course keeping toilets clean and regularly cleaning them not spitting in public or cleaning noses openly were His ideas. The ideas went beyond self rather to soul, to put in perspective He stressed about cleaning toilets oneself regularly, and He didn't preach just, He practiced what He said, and regularly cleaned the toilets of Gandhi Ashram himself. His ideas of abolishing manual scavenging and be a scavenger oneself went beyond personal cleanliness to perhaps cleanliness of one's souls. To the extent He ones said that as society we have failed our manual scavenger, the very idea was to promote a casteless society.

The full extent of Gandhiji's emphasis on cleanliness didn't rely only on personal or community hygiene alone; it stressed the very essence of cleanliness of our souls. A Mehtar (Sweeper) by the name of Uka did scavenging in Gandhiji's home at Rajkot. Gandhiji's Mother used to make him take bath whenever He touched Uka. Gandhiji questioned his Mother "How can his touch pollute me" ? He told His Mother that, Lord Rama embraced Guhaka a chandel (A caste considered untouchable), so how can Lord Rama and Ramayana mislead us? His Mother had no answer to this. His morals and thinking were clear and lucid, one who cleans our toilets helps us stay clean are not untouchables neither they are outcaste. He considered scavenging as an art that help us stay clean. It's impressive that He not only stressed on cleanliness but eradicate untouchability and caste system from our society.

Needless to say Gandhiji promoted Khadi and made in India products during His freedom struggle, but never the less He was always open to good ideas from the western world. After His return from England He stressed, that our toilets should be as clean as our Drawing rooms, and He learned it from the West. Many of our health problems are just from the fact that we throw human excreta anywhere and everywhere and many of our diseases and poor health conditions are only due to this that we don't clean our toilets, neither collect treat or dispose human waste as the westerners do. Use of clean lavatories and utensils are essential so is proper disposal and treatment of human excreta. He said that He has accustomed himself to them, and wish that all others should do the same. He insisted that the habit is so firm in him that He never wants to change it. As said earlier it's very hard to contemplate the actions of Great Man like Gandhiji, so profound were His actions at times that even his friends and followers were speechless. Notable to mention, that Gandhiji started scavenging in South Africa, and learnt the fine art there. He said "Scavenging is a fine art" , because the scavenger cleans and disinfects toilets without getting himself dirty. His friends lovingly called Him the "Great Scavenger" and rightfully He said "Everyone must be his own scavenger" . After staying in South Africa for three years He returned to India to get His wife and son's by the time Plague has taken epidemic proportions and chances were it would spread to Rajkot. He instantly offered his services and inspected every home in Rajkot and stressed 
the need to keep latrines clean. What He saw came as a shocker to him, dark filthy stinking pit with vermin, as the residents were wealthy but had absolutely no clean toilet. On His call scavengers responded and cleaned up pits in Rajkot and literally prevented the spread of plague.

During his second trip to India from South Africa He attended the Congress session in Calcutta, to raise the cause of ill treated Indians in South Africa. The sanitary condition of the camp was so filthy, that the veranda in front of the delegate's rooms was used as latrines. Gandhiji reacted immediately and fetched a broom to clean the filth himself. Although astonished to see a man dressed in western clothes doing this work none of the volunteers came forward to assist him, never the less Gandhiji did what He wanted to. Years later when He became the guiding star of Indian National Congress, volunteers formed a Bhangi (Sweeper) squad, where in Brahmins were recruited to scavenge. Two thousand teachers and students were recruited to do scavenging work in Haripura. Gandhiji never thought of recruiting regular bhangi's to do this, and recruited people from upper class, He couldn't label a section of society as untouchable's, He truly wanted to abolish untouchability, caste system and class from our society, and bring in social equality for all.

To Gandhiji the real test of people's standard of cleanliness was the condition of their latrines. So much so, He even said that He described himself a sweeper and would be happy to die so. Gandhiji stayed in Durban in a house built in western fashion. The bathroom had no outlet for water, and commodes and chamber pots used by His family and clerks had to be cleaned regularly, Gandhiji never hesitated to do it, in one such incident He asked his wife to do this, to which she objected, but $\mathrm{He}$ compelled His wife to do the same. Not only this, He even taught his son's the art of scavenging and keeping toilets and latrines clean at a very young age. His motto was clear, chamber pots are not to be cleaned by sweepers always, and every member of the household should clean them.

On 4th February, 1916 at the inauguration of Banaras Hindu University Gandhiji spoke about His visit to Viswanath Temple, a few years back, He recalled how dirty the Temple premises were, and He said how can God's own house be so dirty? "Is not this great Temple a reflection of our own character?" He stressed the need to keep the Temple and surrounding roads and lanes clean. His thoughts were we can't gain God's blessings with an unclean body or mind, and a clean body can't stay in an unclean environment. Ones during one of his meetings to promote khadi, the sweepers were not allowed to attend, on coming to know about this Gandhiji quit the meeting and told the organizers that He is going to hold a meeting with the untouchables, and those who wished to join were welcome. Two years before His death Gandhiji stayed with the sweepers in their colony in Bombay and Delhi for few days, as He wished to share their living space and food with them.

At the age of 46 Gandhiji returned to India and visited Kumbh Mela, and served as a bhangi there, that same year He visited the Servants of India Society's quarters in poona, and cleaned the latrines there, but the members of the colony didn't want Him to do so, to which Gandhiji said "This kind of work qualified one for Swaraj" . During His numerous tours of India not only had He stressed the need for clean roads hygienic toilets latrines in public places, He strongly advocated not to spit and clean nose in public. Gandhiji strongly said that, Our new Government will make sure that the masters living in bungalows have clean latrines, not only should the master's have access to cleaner toilets but they will make sure that their servants and their family members have equally cleaner toilets and live in hygienic conditions. He advocated the idea that villagers often used water from tanks to cook, wash and drink and the same water was used to wash their bullocks and they too drank from it, this is absolutely dirty and raises serious health issues, He pointed that basic elementary sanitation wasn't there, and that diarrhea, cholera dysentery and hookworms, were affecting the village folks.

Gandhiji realized early in His life that the poor state of cleanliness was not only lack of adequate toilets; but also lack of education among the masses, a non reciprocal attitude towards western methods even though they are far better. He realized that one of the main reasons for this was because for the fight for "Swaraj", resources were not diverted towards sanitation, and He said unless we rid ourselves of dirty habits and latrines Swaraj can have no value for us. All along His struggle for freedom, He constantly led a struggle for cleanliness, sanitation and waste management of all kinds. In South Africa Gandhiji was very active for the rights of Indians settled there, and especially because the White settlers didn't give their counterparts the proper treatment, it was also because of sanitation and hygiene He found out that the disparity originated. Those days plague was a major epidemic and the Indian settlers were not at all 
hygienic compared to the South African white settlers and it was of utmost importance to maintain high levels of cleanliness in latrines because of the epidemic. In Durban He took a house to house inspection of latrines of Indian's and was met with bitter opposition.

In South Africa Gandhiji had decided to abolish the twin curse of 'Untouchability' and 'Insanitation' and wrote to the Chief Medical officer of Johannesburg, as the insanitation and overcrowding there could lead to an outbreak of an epidemic. Soon after, plague broke out and Gandhiji asked to adopt sanitation and hygiene as part of being. He advocated the remedy was in our hands, and that our malignant tumors of uncleanliness must be thrown off and it's the duty of the Indian's there to prevent an outbreak there.

Gandhiji pointed out how the educated and affluent Indians approached the scientific European standard of sanitation while those in rural areas stuck to old methods of sanitation. The very morality and economic conditions of people needed a change He suggested. In South Africa He shared his knowledge on health, and wrote a booklet on "General Knowledge about Health" and discussed how latrines in open spaces and those in narrow lanes and urinals were the main source of defilement of air, and attracted flies and other insects and spread diseases. As always He suggested that we clean latrines our self, and said buckets should be used in latrines and when it's full, the contents should be taken far off from living area and dump in at least 1 to 2 feet deep and covered with earth, which in due course becomes manure. It can be safely said that He advocated the principles of sanitation and cleanliness in great intricate detail.

In Gujrat Political Conference Gandhiji said that our houses roads and public buildings were not clean and this allows the epidemics to target us. He went on to say that if we could banish Plague from India then it will be a great step forward, for the fight of Swaraj. In Nizamabad, He noticed that the drains were full of filth and stated that Swaraj ought to begin from our streets, and said not only our houses and latrines should be perfectly clean and well ventilated with plenty of light, we should also have clean drinking water and manage dispose human waste in perfect manner, and He laid down each modalities with explicit detail to deal with excreta when defecating in open and in latrines. At the opening of the Tibbia College in Delhi in 1921, he observed that, the science of sanitation is infinitely more ennobling, though more difficult of execution, than the science of healing, Gandhiji paid special attention to villages, as majority of India's population resided there and were in poverty. He saw how poverty drove people into insanitation, because women mostly had one saree and so could not take bath regularly and would defecate openly. He advised to do so digging a small pit and away from habitation and cover the pit with soil to turn the same into manure. Gandhiji started questioning why we consider people doing the most useful job as 'Untouchables' a task which we should do ourselves. Gandhian movement of cleanliness took a strong shape and when He came out of jail in 1924 He went on to teach us that, outward filth is only a sign of uncleanliness in our minds.

\section{CONCLUSION}

His quest for Swaraj and Cleanliness are so interwoven, it's hard to segregate them. The list of quotes, his quests, lectures and advocacies for cleanliness and sanitation can perhaps never end, even today. He described human waste as matter displaced a beautiful form of English to convert something filthy into useable precious manure. The very ideas of Gandhiji's cleanliness went beyond personal or community, irrespective of any boundaries He just didn't preach, rather practiced. Ones on a visit to a school, He told that You will make your institution ideal, if besides giving literary education, you have made cooks and sweepers of them. His ideas simple and relevant as said "So long you don't take the broom and bucket in your hands, you can't make your town cities clean". Gandhiji's Ashram was a model, where in leftover food vegetable peels were dumped in a pit to make organic compost, night soil was buried in separate pits and the water recycled was used for gardening. Rightly Gandhiji said "Cleanliness is next to Godliness", and in today's era where a pandemic has gripped the world, His words hold true than ever. Relating this great soul only to cleanliness just doesn't justify, His morals thinking were much beyond. Abolishing caste system and class in our society, equality for all, social justice and binding the newly formed Nation to form a strong healthy India, were dreams He cherished. 


\section{REFERENCES}

1. Gandhi, M.K., Key to Health, Nava Jivan Publishing House, Ahmedabad, 1948.

2. Gandhi, M.K., Unto This Last, Nava Jivan Trust, Ahmedabad, 1956.

3. Kripalani, Krishna (ed.), All Men are Brothers, UNESCO, 1958.

4. Gandhi, M.K., Caste Must Go and the Sin of Untouchability, Nava Jivan Publishing House, Ahmedabad, 1964.

5. Gandhi, M.K., Character and Nation Building, Nava Jivan Publishing House, Ahmedabad, 1959.

6. Varma, Ravindra, Mohan Mala, Navajivan Mudranalaya, Ahmedabad, India.

7. January 2019, pp11-16.

8. Chakraborty, Bidyut \& Pandey, Rajendra Kumar, Modern Indian Political Thought, Sage Publication, 2009.

9. D., G., Tendulkar, Mahatma Life of Mohandas Karamchand Gandhi, Pub. Govt. of India, Ministry Of Information and Broadcasting, Patiala House, New Delhi, 15th August, 1951.

10. Anand, Y.P., Collected Works of Mahatma Gandhi, (Vol-1to100), Publication Division, New Delhi, 1958-1994.

11. Pathak, Bindeswar, Sociology of Sanitation, Chapter1-30, Kalpaz Publication, New Delhi, 2013, 2015.

12. Rathi, Subhangi, \& Bandopadhyaya, Anu, Baharoopee Gandhi Scavanger, Popular Prakashan, Mumbai, 1964.

13. Gandhi, M.K., The Mind of M.K.Gandhi, Navajivan Publication, Ahmedabad, 1945.

14. Chakraborty, Tushar, Prakriti Pragati O Sampurna Biplab, Ekok Matra (Bengali Journal), January 2019, pp-11-16

15. http://www.mkgandhi.org website, 25-06-2020. 